\title{
INVOLUNTARY TERMINATIONS UNDER EXPLICIT AND IMPLICIT EMPLOYMENT CONTRACTS
}

\author{
James L. Medoff \\ Katharine G. Abraham \\ Working Paper No. 634 \\ NATIONAL BUREAU OF ECONOMIC RESEARCH \\ 1050 Massachusetts Avenue \\ Cambridge MA 02138 \\ February 1981
}

\begin{abstract}
We greatly benefitted from a number of discussions with Robert Hall concerning an earlier version of this study. Gregory Bialecki, Nancy Earley, Jon Fay, Susan Johnson, and Martin Van Denburgh gave invaluable assistance in carrying out the research to be discussed. The comments and suggestions made by numerous individuals at Chicago, Cornell, Harvard, International Institute of Management (Berlin), Maryland, Massachusetts Institute of Technology, National Bureau of Economic Research, Princeton, Virginia Polytechnic Institute, and Wisconsin were also most useful. The study was supported by a National Science Foundation Grant (DAR-7828104) to the National Bureau. The research reported here is part of the NBER's research program in Labor Studies and project in Productivity. Any opinions expressed are those of the authors and not those of the National Bureau of Economic Research.
\end{abstract}




\section{Involuntary Terminations under Explicit}

and Implicit Employment Contracts

\section{ABSTRACT}

This study investigates where and when last-in-first-out permanent layoff policies seem to go hand in hand with compensation policies under which the net value of senior workers appears to be less than that of their junior peers. The investigation relies upon both the approximately 260 usable responses to a survey we mailed out to a sample of U.S. firms and microdata from the computerized personnel files of a major U.S. corporation. Our findings for U.S. companies outside of agriculture and construction lead us to the following three conclusions: (1) For most employees, it appears that protection against job loss grows with seniority, although net value to the firm does not. (2) While a very sizeable percentage of nonunion workers may be covered by implicit employment contracts which give more protection against termination to those with more seniority, a much higher percentage of workers covered by collective bargaining agreements seem to enjoy such protection; and (3) The job protection afforded senior nonunion personnel, especially exempt employees, appears to be less strong than that provided to union members.

Professor James L. Medoff Department of Economics Harvard University Cambridge, Massachusetts 02138

(617) 495-4209

Professor Katharine G. Abraham Alfred P. Sloan School of Management

Massachusetts Institute of Technology Cambridge, Massachusetts 02139 
At most U.S. work places, junior employees appear to be paid less than the value of their current contribution, while senior employees appear to be paid more. ${ }^{1}$ This phenomenon is consistent with the presence of either explicit or implicit employment contract provisions designed to defer earnings from early to later in the worklife. ${ }^{2}$ Contract provisions under which compensation is deferred to late in the working years have been hypothesized to be attractive to the parties involved because, for one or more of a variety of possiblereasons, workers can be offered any given level of expected utility at a lower expected cost to the employer than if wage equalled value marginal product at each point in time. ${ }^{3}$ An earnings provision of this sort could produce a positivelysloped seniority-earnings profile even if productivity was constant or decreased with tenure. Under the provision, employees with greater-thanaverage company service are paid more than the value of their contribution in return for having accepted earnings less than their contribution at the start of their tenure.

One would expect that an explicit or implicit contract with a pay provision like the one just discussed would also have a provision designed to protect workers from being cheated out of the return promised for the second half of their work1ives. At least in the U.S., the nost common type of provision providing this protection found in explicit (union) contracts is one which calls for layoffs in inverse seniority order. ${ }^{4}$ But what goes on in nonunion settings? How prevalent are implicit last-in-first-out termination policies? Are they as binding in all states of nature (that is, as "strong") as those which are found under unionism?

In this paper, we assess the likely prevalence of implicit contract provisions under which senio: employees are protected against being laid of s before junior employees by studying whether, in the absence of a union contract, junior employees 
are sometimes terminated while senior employees keep their jobs, in spite of the perceived net value of the senior employees being less than that of their terminated junior compatriots. ${ }^{5}$ We also assess the likely "strength" of putative implicit contract provisions pertaining to the order of layoffs by looking at outcomes in various states of nature."

In the first section, we summarize the large amount of evidence which supports the proposition that junior employees in a wide variety of occupations are typically paid less than their current value marginal product while their senior co-workers are typically paid more. These studies strongly suggest that schemes under which pay is deferred from early to later in the worklife are the rule, not the exception, throughout the U.S. economy.

In Section II, we lay out a simple framework for discussing the role an implicit contract provision pertaining to terminations can play in bringing the ex post interests of the employer and his/her employees closer together. We then presant evidence to support the argument that, in the absence of any implicit contract provision governing terminations but given existing wage and productivity profiles, employers would typically want to terminate senior employees before junior employees. Thus, a last-in-first-out rule could potentially play a key role in conditioning employees' permanent layoff decisions. Finally, we discuss why a last-in-first-out layoff rule might be the preferred approach to protecting employees' deferred earnings.

Section III offers an empirical assessment of where and when last-infirst-out termination policies do in fact protect potentially vulnerable senior 
employees from losing their jobs when workforce cutbacks occur. This assessment relies upon both the approximately 260 usable responses to a survey we mailed out to a sanple of U.S. firms and microdata from the computerized personnel files of a major U.S. corporation. Our findings for U.S. companies outside of agriculture and construction lead us to the following three conclusions: (1) For most employees, it appears that protection against job loss grows with seniority, although net value to the firm does not. (2) While a very sizeable percentage of nonunion workers may be covered by implicit employment contracts which give more probaction against termination to those with more seniority, a much higher percentage of workers covered by collective bargaining agreements seen to eniny such protection; and (3) The job protection afforded senior nonunion personnel, especially exenft employees, appears to be less strong than that provided to union members. In Section IV, we sumarize the main conclusions of our analysis and offer some suggestions for future research.

\section{Evidence on the Relationship of Tenure to Wages and Productivity}

Examination of available data reveals that, controlling for occupation and industry, length of company service tends to be positively related to wages. Previous studies have provided a large body of evidence which strongly suggests that, again controlling for occupation and industry, productivity bears either no relationship or a negative relationship to length of service after a short initiation period. When juxtaposed, these two sets of findings seem to imply that senior (junior) workers are indeed typically paid more (less) than their value marginal product.

One source of data on the relationship of tenure to rate of pay 
is the Panel Study of Income Dynamics (PSID) conducted by researchers at the University of Michigan. We estimated separate ln(hourly wage) equations for blue collar workers and for managers and professionals using 1971 PSID data and 1974 PSID data (a total of four separate samples). Our results are presented in Appendix A. Controlling for 1-digit industry and 1-digit occupation, those with less than 3 years of tenure earned between 13 and 20 percent less than those with 3 to 10 years tenure (coefficient statistically significant in all four sarples) and those with more than 20 years of tenure earned between 10 and 12 percent more than those with 3 to 10 years of tenure (coefficient statistically significant in three of four samples) 8

While tenure appears to be positively related to earnings both among blue collar workers and among managers and professionals, there is a great deal of evidence which strongly suggests that in most occupations additional service is not positively related to productivity. We have completed an exhaustive search of the extant literature on the relationship between an individual's tenure (or experience or age) and his/her productivity; all 26 studies which we were able to locate are summarized in Appendix B. 9, 10 The large body of available evidence provides support for the following stylized facts: (1) Among managers and professionals, employees who have greater-thanaverage service typically perform less well than employees with similar assignments who have less-than-average service (but are beyond the typically. short orfentation period); and (2) Among hourly employees (beyond a normally even shorter orientation period), seniority is usually unrelated to productivity among those performing comparable work. When considered together with the evidence from the PSID that wages have a strong positive relationship with tenure, what we know about the relationship of productivity to tenure makes it seem likely that more (less) senior employees are generally paid more (less) than their value marginal product. 
This conclusion might be criticized on the grounds that the wage results and the productivity results we have compared do not really mesh insofar as the two sets of findings were derived using different samples and arguably incompatible methodologies. Among the productivity studies we reviewed, those completed by the authors and by their students (Medoff 1977, Medoff and Abraham 1980a and forthcoming, Halasz 1980, and Yanker 1980) weredesigned specifically to test whether the higher earnings of more senior employees could be justified on the basis that the senior employees were better performers than junior employees doing comparable work.

At each of the four companies whose personnel data were analyzed in our earlier papers (one airline and three manufacturing firms) approximately 40 percent of the return to company service among white male exempt ${ }^{11}$ employees occurred within job grade levels. The central issue addressed in these studies was whether this consistently substantial within-grade-level return to seniority could be explained on the basis of more senior employees being relatively more productive than less senior employees in the same grade level.

To answer this question, we constructed measures of relative within-gradelevel productivity based on performance evaluations for each white male exempt employee at each of our four firms. Our underlying assumption was that white males in a grade level who received higher performance ratings vere relatively more productive than comparable employees in the same grade level who received lower performance ratings. This assumption seemed reasonable since, at each of the companies we studied, jobs were grouped into grade levels on the basis of their importance and difficulty. In each case, we found that while additional company service was associated with being higher in the relevant within-grade-level salary distribution, it was associated with being lower in the relevant within-gradelevel performance distribution. 
Halasz (1980) applied the same methodology to data for a sample of nonunion production and warehouse employees. For this group, approximately half of the return to company service occurred within grade levels. While additonal company service beyond the mean amount was associated with a higher probability of being towards the top of one's within-grade-level salary distribution, it was associated with a lower probability of being towards the top of one's within-grade-level performance distribution. In Yanker's (1980) sample of blue collar union employees, approximately 80 percent of the total return to seniority occurred within departments; none of this withir-department return could be explained by reference to measured productivity. Our earlier studies, the Halasz study and the Yanker study all indicate that sentor employees tend to be overpaid relative to junior employees performing work of comparable difficulty and importance. ${ }^{13}$

The aforementioned studies focus on within-assignment earnings differentials. Medoff and Abraham (1980b) summarizes data collected with the survey instrument discussed at length below ${ }^{14}$ which strongly suggests that approximately 50 percent of our country's private sector nonagricultural nonconstruction employees work in settings where' senior employees are favored substantially when promotion decisions are made. ${ }^{15}$ Hence, for this half of the U.S. workforce, it appears that the piece of the total monetary return to seniority which can be linked to senior employees having been promoted to better-paying jobs than are held by otherwise comparable junior employees is to a signficant extent a reward to seniority per se, rather than simply a reward for higher productivity. Moreover, it should be noted that the 50 percent figure estimates the percentage of the workforce employed where senior employees seem to be favored substantially in promotion decisions; the percentage working where senior employees are favored at all is 1ikely to be much greater. This is because in many settings senior employees can be 
expected to have a significantly higher probability of being promoted than their junior colleagues when the comparisons are limited to those with the same productivity. 16

In sum, even when seniority independent of productivity is not rewarded in promotion decisions, the evidence pertaining to within-grade or within-job earnings differentials strongly suggests that, overall, seniority per se is handsomely rewarded in most firms' compensation policies; for the 50 percent or more of the labor force for which seniority in and of itself seems to enhance promotion possibilities, this conclusion holds a fortiori. That is, it appears that the vast majority of the U.S. workforce is employed where a significant fraction of earnings are deferred from early to later in the worklife. Thus, it would seem that employees would seek policies that would protect the interests of those who have been "underpaid" for some period and anticipate being "overpaid".

II. Why We Might Expect to Find Last-In-First-Out Termination Provisions We begin this section by offering a simple framework for discussing how an employer who faced given wage profiles and productivity profiles might make termination decisions and how an implicit contract provision pertaining to terminations might affect those decisions. Next, we argue that available empirical evidence implies that in the absence of any implicit contract provision pertaining to terminations, but given the actual compensation and contribution structures, U.S. employers would typically be more likely to terminate senior employees than junior employees. Thus, 1ast-in-first-out implicit contract provisions could potentially play an important role in conditioning firms' termination decisions. Finally, we discuss why inverse-seniority-order termination policies might be the method chosen for protecting employees' returns under the deferred compensation schemes which we believe are common in the U.S. economy (as discussed in Section I). 
The Simple Framework

Let us define the "net value" of employee $j$ to a firm about to terminate some workers $\left(s_{j t}\right)$ as follows:

$$
\begin{aligned}
& \text { (1) } s_{j t_{0}}=v_{j t}-w_{j t_{0}}+t \sum_{\sum_{0}}^{T}+1 e_{j t}\left(v_{j t}-w_{j t}\right) \frac{1}{(1+r)^{t-t_{0}}} \\
& +c_{j t_{0}}-\sum_{t=t_{0}+1}^{T} p_{j t} c_{j t} \frac{1}{(1+r)^{t-t_{o}},}
\end{aligned}
$$

where $v_{j t}$ is the value marginal product of worker $j$ in period $t ; w_{j t}$ is the wage of $j$ in $t ; T$ denotes the end of the firm's planning horizon; $e_{j t}$ is the probability that $j$ would not have left the firm voluntarily in or prior to $t ; r$ is the appropriate discount rate; $c_{j t}$ represents the expected present value as of period $t$ of the cost to the firm of replacing $j$ if he/she were to leave in $t$; and $p_{j t}$ represents the probability that $j$ will quit or voluntarily retire from the firm in $t$.

The first three terms in the expression for $s_{j t_{0}}$ capture the expected present value of any gap(s) between what $j$ contributes to the firm and what $j$ is being paid in the current and in any relevant future period. The terms involving $c_{j t}$ 's reflect the fact that terminating those workers doing each affected job who would have been most likely to quit or retire anyway will reduce the firm's expected hiring and training costs below what they would have otherwise been.

A profit-maximizing firm which had to let some employees go would wish to terminate employee 1 before employee 2 in period $t_{0}$ if $g_{1 t_{0}}<g_{2 t}$, with

$$
\delta_{j t}=s_{i t}+t_{0}^{\sum_{=}^{m}} t_{0} a_{j t} \cdot \frac{1}{(1+r)^{t}-t_{0}},
$$


where $a_{j t}$ represents the expected value of the costs (not reflected in $s_{j t}$ ) to the firm in period $t$ if it terminates $j$ in $t_{0}$, such as costs associated with current and prospective employees' reactions to $j$ 's termination or those associated with the severance pay received by $j$, and $T$ again denotes the end of the firm's planning horizon.

In determining the order of permanent layoffs, the firm would consider both the net value of each employee and the costs associated with his/her termination. Therein lies the potential for an implicit contract provision which affects the $a_{j t}$ 's. For example, a firm that was operating under a last-in-first-out implicit contract provision might incur costs stemming from reluctance of new employees to join the firm, bruised workforce morale, and/or increased employee interest in unionization if it terminated senior employees before junior employees.

Assessing the existence and strength of implicit employment contracts pertaining to order of involuntary terminations requires that we determine the relationship between the $s_{j t_{0}}$ of equation (1) and employee seniority. If the $s_{j t}$ is larger for senior workers, then an implicit contract provision under which the costs of terminating rises with years of service would have a definite role; it would give senior employees job security they would not ntherwise enjoy, given the existing wage and productivity profiles. If the $s_{j t}$ did not decline with seniority, it would be impossible to test for the existence of a last-in-first-out implicit contract provision; in this case, we would not expect an employer to terminate senior workers first even in the absence of an implicit contract provision proscribing such conduct. Potential Vulnerability to Job Loss During a Crisis

In very bad states of nature, we can expect that the firm's discount rate will be very high $(r \rightarrow \infty)$ or, to put it differently, that the firm's planning horizon will be very short $\left(T \rightarrow t_{0}\right)$ and that the firm will not be replacing employees 
who voluntarily depart. In this scenario, an employer would want to be rid of employee 1 before employee 2 if:

$$
\text { (3) } v_{1 t_{0}}-w_{1 t_{0}}+a_{1 t_{0}}<v_{2 t_{0}}-w_{2 t_{0}}+a_{2 t_{0}}
$$

Thus, in very bad states of nature, only the current wage, current productivity, and current termination costs are likely to determine which employees a firm 17 terminates.

There are at least two good reasons to believe that the approximation $r \rightarrow \infty\left(T \rightarrow t_{0}\right)$ is not unreasonable insofar as decisionmaking related to permanent layoffs is concerned. First, firms that find themselves cutting back their employment through permanent layoffs most typically are encountering very difficult economic conditions. For such firms, doing well enough in the current period to survive into the next period is apt to be a very real consideration. Second, for the person actually charged with deciding which employees should be terminated, taking steps which increase profits in the current period is apt to seem particularly important. An executive who fails to produce immediate results may find his/her job on the 1 ine. ${ }^{18}$ We believe we showed in Section I that the gap between current wages and current productivity is typically greater for senior employees than for junior employees in most occupations. Thus, $v_{j t_{0}}-w_{j t}$ in (3) above is apt to be smaller for senior than for junior employees. Since the approximation $r \rightarrow \infty\left(T \rightarrow t_{0}\right)$ is likely to be auite reasonable when permanent layoffs are occuring, employment contract provisions affecting the $a_{j t}$ 's in $_{0}$ (3) in such a way that the current costs of terminating senior employees exceed the current costs of terminating junior employees could play an important role in conditioning firms" ex post termination decisions. 


\section{More Evidence Concerning Potential Vulnerability to Job-Loss}

A good argument can be made for believing that those employees valued least by the firm and, hence, potentially most vulnerable to job loss in the absence of any contract provision governing terminations are the same employees whose voluntary departures would be least regretted by the firm. We can write the firm's net loss from $j$ quitting in $t_{0}\left(d_{j t_{0}}\right)$ as:

$$
d_{j t}=s_{j t}+t_{0}^{\frac{T}{\Sigma}} t_{0} a_{j t}^{\prime} \frac{1}{(1+r)^{t-t_{0}}}
$$

where the a' $j$ terms capture the indirect costs related to other current and prospective future employee's reactions to employee j's quit; which are incurred by the firm in period $t$ if $j$ departs in period $t_{0}$. The $\dot{a}_{j t}$ terms are intended to pick up costs associated with such things as change in workforce morale or change in ability to recruit desirable employees, resulting from j's "voluntary" separation.

If $\sum_{t=t_{0}}^{T} a^{\prime} j t \frac{1}{(1+r)^{t-t_{0}}}$ is the same for all employees, $s_{1 .}$ will be greater than $s_{2 t}$ (employee 1 will have a higher net value than employee 2) whenever $d_{1 t}$ is greater than $d_{2 t}$ (that is, whenever employee 1 's quit is more regretted than employee 2's quit). There is no good a priori reason for believing that $\sum_{t=t_{0}}^{T} a^{\prime} j t \frac{1}{(1+r)^{t-t_{0}}}$ should be systematically related to seniority. On the one hand, quits of long service employees might lower workforce morale. On the other hand, by opening up promotion possibilities, voluntary separations of senior employees would most likely enhance employee's perceptions of how quickly they might get ahead at the firm.

If we accept the seemingly reasonable assumption that $\sum_{t=t_{0}} a_{j} \frac{1}{(1+r)^{t}-t_{0}}$ is not associated with seniority, evidence that senior workers' quits were less likely to be regretted than junior workers' quits would indicate that the 
perceived net value relevant for ex post termination decisions is less for senior employees than for their junior compatriots. This would mean that an implicit contract provision affecting the $a_{j t}$ 's of (2) above in such a way that the present value of the costs associated with terminating a senior employee exceeded the present value of the costs associated with terminating a junior employee could play an important role in influencing firms' cx post termination decisions.

From 1971 to 1976, Company C collected data which allowed us to annroximate relative $d_{j t}$ 's for all exempt emplovees in a given orade. During. this period, supervisors at Company $C$ were asked to label the quits of their exempt subordinates as "regretted," "nonregretted," or "encouraged." In the 1973 to 1975 period (the years to be analyzed below), among white male exempt employees (the group to be studied), 68 percent of all quits were regretted, 18 percent were nonregretted, and 15 percent were encouraged. It seems reasonable to assume that employees whose departure was "regretted" had djts larger than the ${ }_{j t}$ 's of employees whose departure was "nonregretted" or "encouraged." 19

While it is possible to estimate the effects of various employee characteristics on the extent to which quitters' departures are regretted, these estimated effects could well represent biased estimates of the relationships between the characteristics and degree of regret over auit for the company's workforce as a whole. Given the way the U.S. labor market for managerial and professional employees seens to operate, we were concerned that the partial correiation detween value to the firm and company service would be more positive (or equivalently less negative) for Company C's quitters 
than for Company C's entire exempt population. If this were the case, simple estimates of the relationship between supervisors' degree of regret over quits and years of company service, using data for a samp.e of auitters, would understate the extent to which the departure of the typical employee with more-than-average service would be less regretted than the departure of the typical employee with below-average service.

The potential importance of sample selection bias of the type we are considering was raised in the influential piece by Heckman (1976). A maximum likelihood procedure to deal with sample selection bias (also providing consistent standard errors, which Heckman's Mills' ratio procedure does not) was developed and discussed by Criliches, Hall and Hausman (1978). We modified this maximum likelihood procedure to deal with sample selection bias when the dependent variable in the equation of concern is dichotomous ("quit regretted" versus "quit not regretted") rather than continuous and computed joint maximum likelihood estimates of: (1) $\underset{\sim}{\beta}$, the vector of coefficients in a probit equation with quit/not quit as the dependent variable; and $(2) \underset{\sim}{\delta}$, the vector of coefficients in a probit equation with quit regretted/ not regrietted as the dependent yariable. The errors in the quit equation and in the regret equation were assumed to be distributed bivariate normal, $B\left(\sigma_{1}, \sigma_{2}, \rho\right)$, where $\sigma_{1}$ is the standard deviation of the error in the quit equation, $\sigma_{2}$ is the standard deviation of the error in the regret equation and $\rho$ is the correlation between the errors in the two equations.

The likelihood for an observation on a person who did not quit can be written:

(4)

$$
\frac{1}{\sqrt{2 \pi} \sigma_{1}} \underset{\sim 1 \sim}{\mathcal{f}} \underset{\sim}{\infty}-\exp \left\{-\frac{1}{2}\left(\frac{y_{1}}{\sigma_{1}}\right)\right\} \mathrm{dy}_{1},
$$


the likelihood for an observation on a person who quit and was regretted can be written as:

(5)

$$
\begin{aligned}
& \underset{\sim 2 \sim}{X_{\sim} \delta} \quad x_{1} \beta \\
& -\exp \left[-\frac{1}{2\left(1-\rho^{2}\right)}\left[\frac{\mathrm{Y}}{\left(\frac{1}{\sigma_{1}}\right)^{2}}\right.\right. \\
& \left.+\left(\frac{\mathrm{Y}_{2}}{\sigma_{2}}\right)^{2}-2 p\left(\frac{\mathrm{Y}_{1}}{\sigma_{1}}\right)\left(\frac{\mathrm{Y}_{2}}{\sigma_{2}}\right)\right\} \mathrm{dy}_{1} \mathrm{dy}_{2} \text {, }
\end{aligned}
$$

and the likelihood for an observation on a person who quit and was not regretted can be written:

(6)

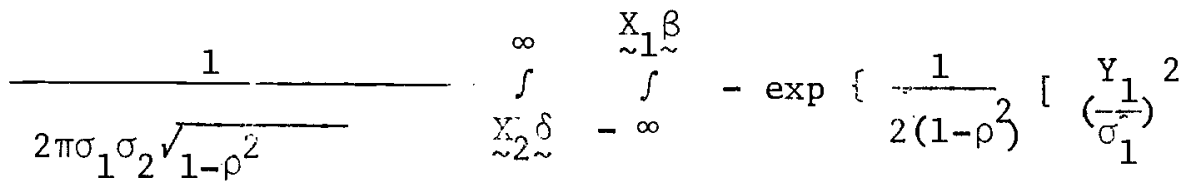

$$
\begin{aligned}
& \left.\left.+\left(\frac{\mathrm{v}_{2}}{\sigma_{2}}\right)^{2}-2 \rho\left(\frac{\mathrm{x}_{1}}{\sigma_{1}}\right)\left(\frac{\mathrm{Y}_{2}}{\sigma}\right)\right]\right\} \mathrm{dy}_{1} \mathrm{dy}_{2} \text {, }
\end{aligned}
$$

where $\underset{\sim 1}{X_{1}}$ is the vector of independent variables included in the quit equation and $\mathrm{x}_{2}$ is the vector of independent variables included in the regret equation. Neither $\sigma_{1}$ nor $\sigma_{2}$ is identified; we set both equal to 1.20

Table 1 presents estimates of the coefficients from a simple probit regret equation and of the coefficients estimated for the regret equation using the maximum likelihood technique just described. The simple probit equation coefficient point estimates suggest a declining relationship between probability of a quit being regretted and tenure. However, as discussed above, these estimates are likely to be affected by sample sclection bias. 
The maximum likelihood coefficient estimates more strongly indicate a negative relationship between probability of a quit being regretted and tenure. The maximum likelihood results imply that potential quits of those with more than 20 years tenure are significantly less likely to be regretted than potential quits of those with less than 10 years of tenure. The coefficient on the 10 to 20 years of tenure dummy suggests that potential quits of persons in this company service group are less likely to be regretted than potential quits of persons with less service; however, the relevant estimated coefficient is not statistically significant 21

If among all exempt employees perforning comparable work, $\sum_{t=t_{0}}^{T} a^{\prime} j t \frac{1}{(1+r)^{t-t_{0}}}$ is unrelated to seniority and supervisor's coding of quits as "regretted" or otherwise accurately captures the relative size of the $d_{j t}$ 's of equation (4), then these results have the important implication that the perceived net value relevant for termination decisions of the most senior (those with more than 20 years of company service) exempt employees in any grade level is less than the perceived net value relevant for ex post termination decisions of the least senior (those with less than 10 years of service) exempt employees in the same grade. This means that if an implicit contract provision under which the present value of the costs of terminating an employee is positively related to the employee's company service is operative at Company $C$, the relationship of seniority to probability of termination among Company C's exempt employees nay look quite different than it would in the absence of such a provision, all else the sane. ${ }^{22}$

\section{Why Last-In-First-Out Layoff Rules?}

Thus far in this section, we have argued that, given existing wage and productivity profiles, a last-in-first-out implicit contract provision which affected the relative losses to the firm associated with terminations 
of junior versus senior employees could play an important role in conditioning firms' termination decisions. We have not yet discussed why a last-infirst-out rule might be the method actually chosen for protecting employees' rights to their deferred compensation. However, it must. be recognized that this rule is only one of a set of possible mechanims for protecting employees' deferred earnings. For example, one might observe any of the following: a severance pay scheme under which all terminated employees were given the present value of the return due to them; a rule under which permanent layoffs were forbidden; or a policy under which the probability of termination would be inversely related to the present value of the amount of pay deferred.

If we allow for administrative costs, each of these protection mechanisms has strengths and each has weaknesses. While we cannot "prove" that a last-in-first-out rule would be the one chosen from the feasible set, this rule seems quite appealing for three princiral reasons: (1) A policy under which terminations are by inverse seniority should discourage employers from using permanent layoffs, since those let go first would have to be junior employees who on average contribute the most relative to what they are paid. (2) Since permanent layoffs usually affect only a small percentage of a firm's work force, terminating employees in inverse seniority order would generally protect those employees who are owed the greatest amount, namely those who have just reached the point where their pay equals their current contribution and who are looking ahead to a period of pay greater than current contribution. (3) A last-in-first-out rule can be administered, monitored, and (if necessary) justified at low cost.

While there is much evidence that employment practices are different for unionized workers than for 23 for unionized workers than for otherwise comparable workers who are not, it still seems most useful to examine collective bargaining agreements in deriving priors about the nature of putative implicit contracts. If virtually all explicit emplsyment contracts seemed to have a given provision, we would expect that a large fraction of 
implicit employment contracts would have the same provision, unless we had some particular reason for believing the opposite. This is both because the relevant production functions and distributions of tastes are not likely to be completely different in union and nonunion firms an 1 because there appears to be some spillover of practices from union to nonunion settings, presumably as a result of the "threat" of unionism.

Under nearly all collective bargaining agreements in the U.S., management has the right to determine the number of employees to be terminated. There are, however, two sets of provisions which are likely to affect termination decisions. One set deals with the order of terminations and the other set deals with severance payments to those terminated.

Union contracts typically state that junior workers must be laid off before senior workers. The most recent relevant study of contract provisions was a BLS analysis of major contracts (those covering 1,000 or more employees) in effect in 19701971. According to the BLS report, 81 percent of the major contract work force was covered by some type of layoff provision. Over two-thirds of the 19 percent not covered by any layoff provision were construction workers; of al1 the construction workers under major contracts, on $1 y$ percent were covered by any type of layoff provision. Examination of a sample of those contracts which contained layoff provisions showed seniority to be the "sole" or "primary" factor in determining layoff rights for 78 percent of the workers covered by contracts in the sample, exclusive of those workers covered by contracts in which the issue was "subject to local negotiations." 24

While last-in-first-out layoff provisions appear to have been found in the vast majority of union contracts since the advent of industrial unionism, severance pay provisions are a relatively new phenomenon. These provisions, under which terminated employees are normally given a lump-sum reward based on their years of service and wage at separation, have grown in importance substantially during the past twenty-five years. Despite this growth, only 37 percent of the 1978 major contract workforce was covered by 
these plans. Moreover, it should also be noted that a significant

fraction of the employees covered by severance pay provisions are also covered by a provision stating that layoffs must be by inverse order of seniority. 27

It appears that in most unionized firms the interests of senior employees are protected primarily by last-in-first-out layoff policies. It therefore seems sensible to expect to find such policies in nonunion settings. However, there are two key reasons why these provisions might be less prevalent and strong in the absence of a union. First, the weights attached to a given set of preferences are likely to he significantly different under unionism; in particular, senior employees can be expected to have much more power relative to their junior co-workers under unionism. ${ }^{28}$ second, the fact that implicit contract provisions pertaining to the order of terminations are not enforceable under U.S. law (which is not the case for explicit provisions) is likely to affect the way in which senior employees' interests are supposed to be protected in nonunion firms and the extent to which this expected protection is in fact delivered. $2 \ddot{9}$

Despite these potentially important reasons for union-nonunion differences, $\underline{\text { a }}$ priori $\operatorname{logic}$ and union contracts strongly suggest that if implicit contracts exist, they are very likely to have last-in-first-out termination provisions accompanying the compensation provisions they would seem to have.

III. On the Likely Prevalence and Strength of Implicit Last-In-First-Out Layoff Provisions

In this section, we first present the results from our survey of U.S. firms dealing with their policies concerning permanent layoffs. We then analyze the terminations of a firm which we have been studying for a number of years, which in one of these years happened to have a massive reduction in its exempt workforce. 
Results from Our Employer Survey Pertaining to Involuntary Terminations

Evidence used to determine the existence of implicit contract provisions concerning the order of terminations should meet two criteria. First, it should reflect the pattern of terminations on a firm-by-firm basis. When data which do not 1 ink individuals to particular enterprises are used, it is impossible to tell whether any particular termination is one of a small number at many firms or one in a major cutback at one firm. This is important because if a weak implicit contract were operative at most firms, then we would expect senior workers to be more likely to be terminated in major upheavals. A reasonable guess is that a high overall layoff rate is more likely to be reflecting major staff reductions at the relevant firms than a low layoff rate, but we cannot be sure. Differences in the distribution across tenure categories of those employed at firms experiencing permanent layoffs and those employed at firms not terminating employees could also lead to misleading results. These factors prevented the use of some data sets which at first blush seemed to be obvious sources, namely the PSID and the National Longitudinal Survey (NLS), Second, the evidence should reflect the arrangements of a sufficiently large number of firms to allow us to generalize about how permanent layoff decisions are typically made. To generate the requistte data on the policies governing terminations among various employee groups at different firms, we developed and mailed out the employer survey which is reproduced in Appendix C. 
The original sample of firms which were to be sent our survey consisted of 1000 randomly selected companies from the 1979 edition of Standard and Poor's Register, 200 randomly selected companies from the 1977 News Front list of the 1,000 largest manufacturing firms and 50 randomly selected companies from the 1977 News Front. list of the next 2,000 1argest. ${ }^{30}$ We chose to oversample manufacturing by adding companies from the News Front lists to our Standard and Poor's sample of firms because of the very large fraction of the economy-wide variation in employment which occurs in this sector. After those firms from the 1979 Standard and Poor's Register which were foreign based, those to whom mail was not deliverable at the address given in the 1979 Register, those not included in the 1980 Register, and those in the News Front sample that were also in the Standard and Poor's sample were deleted, we were left with a mailing list of 884 Standard and Poor's firms plus 241 News Front firms.

Whenever possible, we mailed our survey to that individual at each firm who appeared to be in charge of personnel matters (e.g, the Executive Vice President for Personnel, the Personnel Director or the Industrial kelations Vice President). In cases where no such indiviudal's name could be obtained, the letter was sent to the Chief Executive officer of the corporation. The recipient of the letter was told "Since your firm is part of a scientifically selected sample, it is crucial that we receive a response to this very short questionnaire from you or a colleague who makes decisions concerning the management of human resources." If no response was received from a firm within a month after our first request was mailed, a second request was sent to the original contact. 
Of the 1125 surveys we mailed out, 2 percent were not deliverable as addressed; 3 percent were sent back to us by firms that did not satisfy the criteria specified for participation in the survey; 3 percent were returned with a refusal; 6 percent were completed and returned but could not be used because of data problems; 27 percent were otherwise acceptable but could not be used because they were filled out by respondents who had no experience with permanent layoffs; and 23 percent were acceptably completed by respondents who had experience with permanent layoffs. Only 35 percent of those on our mailing list were unaccounted for.

The persons who actually replied to our survey tended to be high-level corporate executives. Of the 561 people who returned accurately completed survey forms to us, 7 percent were Chairmen, 29 percent were Presidents, 27 percent were Vice Presidents, 14 percent were Directors, 11 percent were Managers, and 12 percent held other titles.

The most important item on the survey is Question 10.

In the event of a reduction in the workforce, would one of the senior employees in the largest group of employees who are affected by your decisions concerning the management of human resources] ever be involuntarily terminated, that is, laid off permanently against his or her will, in place of a junior employee?

\section{Yes, if the junior employee was considered a better} performer than the senior employee.

Yes, if the junior employee was considered a significantly better performer than the senior employee.

L. No, never. 
The employee group referred to could consist of houly employees, non-exempt salaried employees or exempt employees. We also asked whether or not a majority of those in the affected employee group were covered by a collective bargaining agreement, whether permanent layoffs had ever been used to reduce the size of the affected employee group, and, if the previous question was answered "yes", what proportion of the affected employee group had been terminated in the most recent two permanent layoffs. In addition, we collected the respondent's address (from which we created a region variable), number of people employed by the firm (rhich in 1 n untts became our size-of-firm measure), and information on products produced by the firm (from which we constructed industry dummies).

Table 2 summarizes the responses to our question regarding whet her a junior employee would ever be involuntarily terminated in place of a senior employee. In discussing the table, we focus on the economy-wide (except for agriculture and construction) Standard and Poor's sample. In this sample, the vast majority of the responses for nonunion employee groups indicated either that a senior employee would have to be a significantly worse performer than a junior employee to be laid off first or that a senior employee would never be laid off before a junior employee; the relevant percentages are 76 percent of nonunion hourly responses, 78 percent of non-exempt salaried responses, and 44 percent of exempt responses. If those making permanent layoff decisions typically use high discount rates (which is not unreasonable as explained above) ani if the senior nonunion employees referred to by each respondent typically earn more 
than junior nonunion employees referred to by the same respondents (as can be expected), then these data are supportive of the claim that approximately 70 percent of the nonunion employees in this country (outside of agriculture and construction) are covered by an implicit contract provision which affords extra protection against job loss to senior workers.

While the frequencies in Table 2 are quite consistent with the assertion that implicit contract provisions concerning the order of involuntary terminations are not uncommon, they also indicate clearly that senior workers are most likely to be protected against losing their jobs prior to junior workers where there is a collective bargaining agreement. Even when we limit our comparison to hourly employees, we observe that while almost 76 percent of the respondents discussing nonunion hourlies indicated that a senior employee would not be terminated before a junior employee unless the junior employee was at least a significantly better performer (and at some firms would never be terminated before a junior employee) almost 95 percent of the responses pertaining to union hourlies fell into this category. This difference is statistically significant at the .01 leve1.

Are some groups of nonunion employees more likely than others to be covered by strong implicit contract provisions under which a firm would never terminate a senior employee prior to his/her junior co-worker? Our survey results imply that this type of strong protection is much more prevalent for nonunion hourly employees than for nonunion salaried employees. In the Standard and Poor's sample, almost 28 percent of the responses for nonunion hourly employees, but fewer than 6 percent of those for nonexempt salaried employees and none of those for exempt employees, indicated that a senior employee would never be terminated before a junior employee. Both hourly versus salaried differences are significant at the .01 level. 
Our survey results also imply that very strong protection, such that a senior employee would never be permanently laid off before a junior employee, is very much more prevalent under unionism. Even when only hourly employees are considered, the responses from the Standard and Poor's sample suggest that 68 percent of union hourly employees (outside agriculture and construction) work in settings where the senior worker would never be let go before a junior worker; the comparable figure for nonunion hourly workers, as reported above, is 28 percent. This difference is significant at the .01 level.

The responses to our employer survey can also be used to address the following questions, which seem most pertinent to the issues at hand: Can the apparent union-nonunion differential in the extent of protection against involuntary termination afforded senior hourly employees be explained solely in terms of the types of settings in which unions are likely to exist? How is the union-nonunion differential in the extent of this protection related to the fraction of the relevant workforce permanently laid off (which can be assumed to mirror, albeit very imperfectly, the ex post costs involved in providing the insurance under consideration)? Is the operation of a last-in-first-out permanent layoff policy for exempt employees, among whom the overpayment (underpayment) of senior (junior) employees seems to be especially large, likely to depend to a much greater extent on the economic climate than it does for other nonunion employees? To address these questions, we combined the Standard and Poor's and News Front samples and fit the models whose key parameter estimates are presented in Table 3 . 
Models 1 and 2 in Table 3 indicate that the probability that a senior employee might be permanently laid off if a junior employee was a betcer performer is significantly and substantially higher for employees not covered by a collective bargaining agreement than for covered employees, even when firm size, broad industrv and geographic region (ir findel l) or there same factors plus size of largest permanent layoff (in ifole1 2) are controlled for. The estimated coefficients in Model 1 (Model 2) imply that, at the total sample mean values of the other dependent variables, the probability that a senior hourly worker covered by a collective bargaining agreement might be laid off before a betterperforming junior co-worker is $.059(.057)$. For a senior hourly worker not covered by a collective bargaining agreement, the corresponding probability is .156 (.148); for a senior salaried non-exempt employee, .226 (.253); and for a senior exempt employee, $.419(.417)$.

It is Interésting that, at least in model 1 , large firms appear to be significantly less likely to terminate senior employees ahead of ijunior employees who are better performers. One very tentative interpretation of the negative coefficient on $\ln$ (number of persons employed by the firm) might be that large firms incur greater costs if they violate an implicit contract provision concerning order of termination because their acts aremore visible. If the fraction laid off in a firm's largest permanent layoff can be considered an acceptable proxy for the severity of the worst economic conditions a firm has faced, the significant positive coefficient on that variable suggests that, as expected, firms that have faced very bad economic conditions are less likely to have protected senior employees from being terminated before junior employees who are better performers. 
Model 3, by including interactions of employee groups with size of largest layoff, provides a modicum of evidence about the strength of implicit contracts by examining the extent to rhich they seem to protect senior workers as economic conditions, imperfectly measured, worsen. While the exempt employee interaction coefficient just tisses statistical significance, the point estimate suggests that senior exempt employees are substantially more $1 i^{1}$ ely than hourly employees covered by a collective bargaining agreement to become increasingly vulnerable when economic conditions worsen. While our estimated coefficients are not precise, they are consistent with the claim that implicit contract provisions protecting senior exempt employees' jobs are weaker than implicit contract provisions protecting the jobs of other nonunion employees.

As discussed above, one can also try to assess the prevalence of strong contract provisions concerning the order of terminations by looking at the pattern of "no, never" responses to our question about whether senior employees would be permanently laid off before junior employees. We should perhaps mention that when we pooled the Standard and Poor's and News Front responses for hourly employees and fit a probit model which had a dependent variable equal to 1 if a senior worker would never be permanently laid off before a junior worker and which controlled (as in Table 3) for major industry, region, firm size, and size of downturn, we found that the probability of having this very strong type of senior worker protection was substantially (and significantly) greater under explicit union contracts. At the total sample means the probabilities were .627 for those covered by collective bargaining agreements and .323 for those not covered. 
Analysis of Exempt Worforce Reduction at Company $B$

The cross-sectional data from the survey was used to draw inferences about how an individual firm with the relevant implicit contract provision night change its order of layoffs in response to changes in economic conditions. However, only longitudinal data can demonstrate explicitly how patterns of involuntary terminations vary with economic conditions under any one provision. To this end, we examined the changing patterns of permanent layoffs among the exempt employees at a major U.S. corporation which we have studied over an extended period. This examination is especially rich since in one of the years during which we happened to be analyzing the company, it terminated a very substantial fraction of tits exempt workfores.

The models presented in Table 4 describe

the pattern of involuntary terminations among white male managerial and professional employees at Company B's corporate headquarters during a recent year in which the termination rate was normal and during the following six months in which the termination rate was extremely high. The contrast between the two periods is striking. In the normal-layoff period, exempt employees with greater-than-average service were no more or perhaps less likely to be involuntarily terminated than exempt employees with less-than-average service. In the high-layoff period, probability of being involuntarily terminated was strongly and positively related to seniority. These results are consistent with the following two claims: (1) Under normal circumstances, the jobs of senior exempt employees at Company $B$ are protected by an implicit contract provision regarding terminations; and (2) This implicit provision, if it in fact exists, is not strong enough to protect senior exempt employees' jobs in the event of a major cutback. That is, the findings are consistent with the assertion that a weak implicit contract provision protects the jobs of B's senior exempt employees.

$$
\text { Company B's net income was more than l's peront lower (in weal terme) }
$$

in calendar year $t$ than in calendar year $t-1$. During the first half of 
calendar year $t+1$, a new chief executive officer took charge of the company and decided that, in light of the firm's economic position, its work force should be substantially trimmed. No change in the basic nature of the enterprise was contemplated; rather, manpower requirenents were to be reduced through consolidation of operations, particularly at the corporate headquarters level. Those responsible for deciding who should be terminated were instructed that past performance and ability to perform in the revised organization were the basic factors they ought to consider in drawing up their list. Only 2.2 percent of the white males who had held exempt positions at Company $B$ headquarters as of May 31 of year $t$ were involuntarily terminated during the following year. In contrast, 12.3 percent of the white males who had held exempt positons at Company $B$ headquarters as of May 31 of year $t+1$ were involuntarily terminated during the subsequent six months and 17.7 percent were notified that they were on the list of those to be severed as part of the consolidation process initiated by the new chief executive officer.

Table 4 presents two sets of models for assessing the effect of tenure on the probability of a white male holding an exempt position at Company $B$ headquarters losing his job, one set with no grade level dummies included (Equations 1, 3 and 5) and one set including grade level dummies (Equations 2,4 and 6 ). One of our earlier studies (Medoff and Abraham 1980a) focused on the within-grade-1evel relationships between company service and relative salary and between company service and relative performance for exempt employees at Company B. As discussed in Section $I$, none of the substantial within-grade-level earnings advantage associated with company service could be explained by the better performance of long tenure employees. Thus, we have especially good reason to believe that the net value of those Company B exempt employees in any grade level who have more service is substantially below that of those in the same grade level who have less service. 
Equations 1 and 2 indicate that in the lor-termination neriod from June 1 of year $t$ to May 31 of year $t+1$, long-service employees were protected from being involuntarily terminated. None of the estimated tenure dumy coefficients in either the first or second mode1 (one with no grade level dummies and the other controlling for grade level) is significantly different from zero. The point estimates suggest that, a11 else the same, employees with more than 10 years of service were less likely to be terminated than employees with 3 to 10 years service. These results, in conjunction with the findings pertaining to performance versus pay for less sefior and for more senior employees discussed above, are consistent with the claim than an implicit employment contract provision concerning the order of involuntary terminations covers the relevant group of employees at Company $B$. Equations 3 and 4 analyze the probability of actually having been laid off between June 1 and November 30 of year $t+1$ and Equations 5 and 6 focus on the probability of being chosen to be terminated during the same period. These four equations show a very different pattern than Equations 1 and 2 . Whether or not grade level is held constant, there is a strong positive association between company service and probability of either actual or scheduled termination, which is exactly what would be expected if the company made its termination decisions on a purelymeritocratic or (current) net value basis. The Equation 3 coefficient estimates imply that employees with more than 30 years of service, but otherwise average characteristics, are 3.56 times as likely to be laid off as employees with 3 to 10 years; the Equation 4 coefficient estimates, that they are 4.59 times as likely; the rquation 5 coefficient estimates, that they are 3.25 times as 1ikely; and the Equation 6 coefficient estimates, that they are 3.89 times as 1 ikely. We are led to conclude that if any implicit contract provision protects the jobs of senior exempt employees at Company B, it is a weak one. 32 


\section{Conclusions and Directions}

In the preceding pages, we have investigated where and when last-in-firstout permanent layoff policies seem to go hand in hand with compensation policies under which the net value of senior workers appears to be less than that of their junior peers.

Our investigation yielded three seemingly important findings about employment relationships in the U.S. First, roughly 70 percent of our country's nonunion workforce (outside of agriculture and construction) appears to be employed where last-in first-out termination policies go hand in hand with compensation policies under which employees with less-than-average company service are paid below the value of their current contribution and those with greater-than-average service are paid above it. Second, the probability that a group of workers is covered by a policy under which protection against job loss grows with company service even though net value to the firm does not is greater under unionism, even when we limit the comparison to hourly employees in the same broad industry and region working for similarsized companies. Overal1, approximately 95 percent of union members outside of agriculture and construction work under such a policy. Taken together, our figures for nonunion employees and for union employees imply that about 80 percent of our country's total (nonagricultural, nonconstruction) workforce work in settings where senior employees receive extra protection against job 1oss. Third, the provisions under which job securjty is supposed to increase with seniority appear to be "stronger" when part of a collective bargaining contract; that is, even when we examine (roughly) comparable employees, the probability that a senior worker would ever be terminated (no matter how bad the economic conditions) 
before his/her junior co-worker appears to be substantially lower under unionism. While senior nonunion employees have some protection against losing their jobs prior to their junior colleagues, it seems much less likely to be "crisis"proof" than that enjoyed by senior union members.

It is our belief that, for better or worse, our research has raised as many questions for enterprising empiricists as it has answered: Can the other necessary conditions required for the existence of weak implicit contract provisions concerning the order of permanent job losses be shown to hold? How can we explain the apparent union-nonunion differential, even among comparable groups of employees, in the extent to which firms have last-in-firstout permanent layoff procedures in general and those which are strong in particular? Is the ordering by seniority of permanent layoffs observed among unionized workers closer to an "efficient" ordering than what is observed in nonunion settings? 33 What is it about a trade union that moves collective bargaining contracts closer to or further away from an efficient employment contract ?

These questions indicate, at least to us, that the empirical research on implicit employment contracts, as on most issues currently being discussed by economists, has lagged far behind the theoretical work. The questions themselves suggest that to close this gap effort must be channeled in two directions: First, more data on how individuals' utility and firms' productivity are affected by the events about which we do much theorizing must be collected. Second, more information about the institutions which seem to greatly condition economic outcomes must be generated. We believe that as this evidence is collected, the real answers to the questions raised here and elsewhere in our discipline will be forthcoming. 
Footnotes

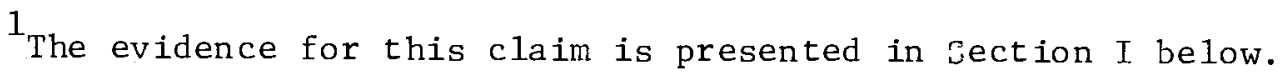

2 Our use of the term "implicit contract" parallels Baily's (1974) and Azariadis" (1975) use of the term in another context.

${ }^{3}$ Becker and Stigler (1974) and Lazear (1979) develop a line of argument in which deterrence of worker cheating motivates entrance into this sort of implicit contract. Salop and Salop (1976) and Viscusi (1978) suggest that steep wage profiles might serve as a self-selection device. A number of other possible hypotheses are outlined in Medoff and Abraham (1980a) and Halasz (1980).

${ }^{4}$ Section II below provides support for this claim.

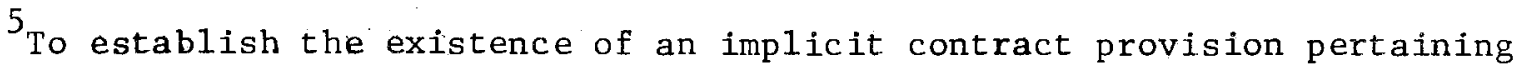
to the order of permanent layoffs, one would want to show that each of the following three conditions was satisfied. First, the firm's decision to enter into the implicit contract which has the provision should be based on an ex ante profit maximizing calculus. This condition merely makes our use of the term "implicit contract" consistent with other authors" use of the term in other contexts. Second, there should be at least some states of the world such that, in the absence of any implicit contract provision concerning the order of terminations, but all else the same, the firm could earn higher profits by laying off a different set of workers than the implicit contract would say should be laid off. Otherwise, there would be no point in having the implicit termination provision. Third, both the firm and its employees should know what the terms of the contract provision are and whether those terms are being adhered to. The second of these necessary conditions $i$ is the only one anlayzed in this study. 
${ }^{6}$ It should perhaps be emphasized that to the extent that the strength of an implicit contract provision concerning order of layoffs can be observed, it will reflect both the terms of the relevant contract and the degree to which those terms are adhered to. In this paper, we make no effort to separate out the roles played by the terms of implicit contracts and by adherence to those terms.

${ }^{7}$ For a more detailed discussion of our survey methodology and results, see Medoff and Abraham (1980c).

${ }^{8}$ Adding controls for education, region, and pre-company experience did not appreciably affect these findings. We also estimated separate in (wage) regressions for union and nonunion blue collar workers. The results of this estimation indicate that while the earnings ratio of those with more than 20 years tenure to those with 3 to 10 years was smaller under unionism in 1971, it was larger under unionism in 1974.

9

Because we felt it was important to make our review of relevant work as comprehensive as possible, we decided to include in Appendix B studies which focused on the relationships of age to productivity and experience to productivity as well as those which looked at the relationship of length of service to productivity. In all of the data sets analyzed for this paper (Company C's exempt employee data, the PSID data and Company B's exempt employee data), both age and experience were highly correlated with tenure. It would be surprising if the relationship of tenure to productivity for those groups covered by the age and experience studies differed greatly from the reported relationship of age or experience to productivity. 10

The criterion that the unit of observation be an individual has led us to exclude a number of studies which examine aggregate data. We know of several educational production function studies which relate the average test scores of groups of students to their teachers' average experience; all of them provide results which imply 
a flat or negative relationship between teachers' "productivity" and their experience after a couple of years of teaching. The one relevant non-educational study that we know of was an analysis of 100 unionized grocery stores done by Walter A. Fogel (1964); this research concluded that unit labor costs were higher in those stores with more senior personnel, which implies that senior grocery store employees were not sufficiently more productive than junior grocery store employees to compensate for their higher salaries.

11 Exempt employees are those in executive, administrative, professional or outside sales jobs and exempt from the overtime provisions of the Fair Labor Standards and Walsh-Healy Acts.

12 See Medoff and Abraham (1980a and forthcoming) for a more thorough defense of the proposition that performance ratings are valid indicators of relative productivity.

${ }^{13}$ It should be noted that none of these results provide unbiased estimates of the effect of company service on either relative pay or relative productivity. This is because more able individuals are most likely promoted more rapidly than otherwise similar but less able individuals, espectally among exempt employees (see Medoff and Abraham 1980b). Thus, even if in any workforce considered as a whole, service was positively related to value marginal product, within a grade level where merit played some role in promotions, one would expect 1onger-service employees to be less able than shorter-service employees and as a result to perform no better. However, if an individual's pay equalled his value marginal product at each point in time, seniority should also have a non-positive partial relationship to within-grade-level salary; these results show that it does not. Thus, we can conclude that senior employees in the relevant populations are most likely paid more than their value marginal product.

${ }^{14}$ The instrument itself is presented in Appendix C below. 
${ }^{15}$ This figure is based on the responses from the representative Standard and Poor's sample discussed below. See Medoff and Abraham (1980c) for a precise statement of how this figure was derived.

16

Evidence supporting this claim is presented in Medoff and Abraham (1980b).

${ }^{17}$ At first blush it might appear that $c_{j t}$ should also appear in (3). However, since we have assumed that a firm will not terminate a worker and then replace him/her during the same period, the present value of the costs of replacing a terminated employee will approach zero as $r \rightarrow \infty\left(T \rightarrow t_{0}\right)$.

18

The assumption that business decisionmakers typically employ a very high discount rate (very short planning horizon) is consistent with much recent writing in the business press. For example, the June 30 , 1980 issue of Business Week states that:

"There is a schizophrenia pervading U.S. business today. It is a rare CEO who has not publicly expounded on the need for focusing on the future--usually couched within a speech castigating government or labor unions for their short-term policies. Yet the compensation systems in their companies, the financial requirements for investment projects, the criteria for management-byobjectives goals and for performance appraisal, all point to an exceedingly short-term orientation." (pp . 74-75).

In addition, it should be pointed out that

earlier empirical work pertaining to the relationship between layoffs and seniority has always, at least insofar as we are aware, implicitly or explicitly assumed that firms use an infinite discount rate (ore period time horizon) in deciding who to terminate. See, for example: Parsons (197\%) and Mincer and Jovanovic (1979), both of which argue that layoffs are principally related to the gap that specific human capital investments are hynothesized to produce between current wage and current value marginal product. 
13

The $\mathrm{d}_{j t}$ 's cajture what supervisors ought to have been thinking about when theycoded their subordinates" quits as "regretted", "nonregretted" or "encouraged". However, when we circulated a questionniare to 15 Company $\mathrm{C}$ employee relations managers to ask them what factors they thought supervisors considered when making regretted/nonregretted decisions, 13 marked "How much the person was contributing to (Company C)" and 2 marked "Whether the person's specialized skills would be easy or difficult to replace" as the most important factors. "The person's potential future contribution to (Company C) was marked by 7 of the 15 managers as the second most important factor influencing regretted/nonregretted decisions. No one said that "How much the person was contributing to (Company C) relative to what he or she was being paid" mattered and only 1 person said that "...how the person's contibution to (Company C) a few years out would most likely have compared to his or her earnings" mattered. These responses suggest that the regretted/ nonregretted codes might alternatively be interpreted as capturing quitters' relative current productivity.

20

We are grateful to Jeffrey Zax for his skilled work on the development of this maximum likelihood model. Gary Chamberlain, Bronwyn Hall, and Jerry Hausman also gave us helpful advice.

21 The maximum likelihood model estimated for Table 1 includes $1 n$ (annual salary), whether ever married, number of children under 18 and whether participating in the company thrift plan in the quit equation, but does not include these variables in the regret equation. While we felt these exclusions to be structurally appropriate, it was not the case that the omitted variables assumed zero coefficients when they were allowed to enter the regret equation. We reestimated our maximum likelihood model without any exclusions and then calculated 
tenure dummy coefficents equal to $\beta_{i}+\sum_{k=1}^{4} \gamma_{i}^{k} \beta_{k}$,

where $i$ incicates the tenure group; $k$ indexes the variables excluded

from our original mode1s; the $\beta^{\prime}$ s are coefficients from the regret

equation in our modified maximum 1ikelihood model; and the $\gamma_{i}^{k}$ s are

coefficients from regressions of each of the originally excluded variables

on all of the other explanatory variables in the new regret equation,

estimated for a representative sample of the Company $C$ workforce. This

procedure produced estimated coefficients of .270 for the 0 to 3 years of

tenure dummy, -. 137 for the 10 to 20 years dummy and -.656 for the more

than 20 years dummy.

22 Med off and Abraham (forthcoming) provides evidence which strongly

supports the claim that Company $\mathrm{C}$ has a deferred compensation policy for

the group of employees under analysis.

${ }^{23}$ For a review of some of this evidence, see Freeman and Medoff (1980).

${ }^{24}$ The figures concerning layoff procedures are from U.S. Department of Labor (1972, pp. 53-54).

${ }^{25}$ For evidence on the early importance of contract provisions stipulating that layoffs would be in accordance with length of service, see Slichter (1941, pp. 115-122). For a discussion of the history of severance pay plans, see Slichter, Healy and Livernash. (1960, pp. 463-469).

${ }^{26}$ This estimate is from U.S. Department of Labor (1978, p. 101).

${ }^{27}$ This fact becomes apparent when one examines the industrial 1ocus of last-in-first-out layoff provisions and the industrial locus of severance pay plans.

${ }^{28}$ This point is discussed at some length in Freeman and Medoff (1980). Its relevance to union/nonunion differences in the importance of layoffs for labor adjustment is addressed. in Medoff (1979). It is also central to

the interesting recent study by Blau and Kahn (1980) who used 1969 to 1971 National Longitudinal Survey data for younger men (aged 17 to 27 ) and for older me:2. (aged 48 to 62 ) to compare and contrast the impact of collective 
bargaining on layoff probabilities among the two groups. Their results for permanent layof s are consistent with the claim that during the sharp downturn from 1969 to 1971, as during the one from 1974 to 1975, the vulnerability to job loss of those with long service relative to those with short service was substantially lower under unionism. It should be mentioned that it is possible that the nonunion preference distribution is more skewed toward present-oriented policies than the union distribution. While this possibility cannot be ruled out a priori, it would seem to become remote as the number of firm and worker controls grows.

29

In contrast to employees who are protected by implicit employment contract provisions pertaining to order of permanent layoffs, those who have entered with their employers into explicit employment contracts dealing with the same issue can turn to the courts for enforcement. In nonunion settings, senior workers usually have no legal protection against being laid off before their junior compatriots. Ignoring situations where a termination has been predicated on a consideration expressly made unlawful by statute(i.e., sex, race, religion, national origin, age, union organizational activity, or protected concerted activity), nonunion employment relationships are generally "terminable at will," regardless of how long an employee has been with his/her employer. Even a written company manual stating that layoffs will occur in inverse order of years of company service will not generally be viewed as an enforceable contract; employers in virtually all jurisdictions have the right to a1ter this "policy" at any time. The one jurisdiction we know of for which this is not the case is Michigan. The Michigan Supreme Court recently held that "an 
employer's express agreement to terminate only for cause, or statements of company policy and procedure to that effect, can give rise to rights enforceable in contract," in Toussaint v. Blue Cross, as reported in Bureau of National Affairs (1980, p. 2823). A senior employee who was involuntarily terminated in violation of a union contract would have lefal recourse. 30

The 1979 Standard and Poor's Register 1isted companies which in 1978 had sales of at least $\$ 1,000,000$ and/or 50 employees and asked to be 1 isted. The 1977 News Front listing of the largest 3,000 manufacturing companies was based on the companies' 1974 sales; this listing was the most recent one available at the time our sample was drawn.

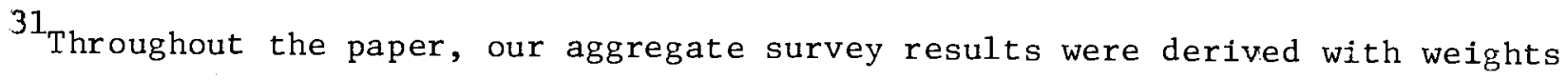
based on weighted counts of private sector wage and salary employees working outside of agriculture and construction obtained from the May 1978 Current Pcpulation Survey (CPS). While the CPS would have permitted us to construct separate weights for non-hourly nonumion employees and non-hourly union employees, we received no responses to our survey which pertained to a non-hourly union group. Our aggregation procedure, which implicitly assumes that the responses for non-hourly union employees would look like the responses for non-hourly nonunion employees, most likely leads to a slight understatement of union/nonunion differentials for the labor force as a whole. 
32

Clearly it would be valuable to obtain information on the pattern of exempt employee terminations during large cutbacks at other firms besides Company B. We do know of at least two additional instances where it had been reported that a disproportionate number of senior managerial and professional employees were terminated during retrenching periods. However, the companies involved would be very unlikely to want to share their data with us; exempt terminations are typically an extremely touchy subject with corporate officials. Furthermore, if we studied firms that we knew had very likely terminated a high proportion of their senior employees, finding that they had in fact done so would not be too surprising. The Company B results are particularly interesting because we were able to observe their layoff as it occured rather than selecting it for study, and because we had access to information in addition to the relevant computerized microdata file which indicated that the company took every step possible to make the cutback meritocractic (that is, based on net value).

33 The concept of an "efficient" employment contract is at the heart of the provocative paper by Hall (1980); his piece contains other relevant references. 


\section{REFERENCES}

Azariadis, Costas. "Implicit Contracts and Unemployment Equilibria." Journal of Political Economy 83, no. 6 (December 1975): 1183-1202.

Baily, Martin. "Wages and Employment Under Uncertain Demand." Review of Economic Studies 41, no. 125 (January 1974): 37-50.

Becker, Gary S., and Stigler, George J. "Law Enforcement, Malfeasance and Compensation of Enforcers." Journal of Legal Studies 3, no. 1 (1974): 1-18.

Blau, Francine D., and Kahn, Lawrence M. "Union Coverage, Seniority and Layoffs." Mimeographed. Urbana: University of Illinois, 1980.

Bureau of National Affairs, U.S. Law Week (June 24, 1980): 2823. Freeman, Richard B., and Medoff, James L. "The Two Faces of Unionism." The Public Interest, no. 57 (Fal1 1979): 69-93.

Fogel, Walter A. "Job Rate Ranges: A Theoretical and Empirical Analysis." Industrial and Labor Relations Review 17, no. 4 (July 1964): 584-597.

Griliches, Zvi; Hall, Bronwyn; and Hausman, Jerry. "Missing Data and Self Selection in Large Pane1s." Annales de L'INSEE, no. 30-31 (Apri1 - September 1978): 137-186.

Ha11, Robert E. "Employment Fluctuations and Wage Rigidity." Brookings Papers on Economic Activity, no. 1 (1980): 91-123.

Halasz, Peter Jonathan. "What Lies Behind the Slope of the Age-Earnings Profile." Senior honors thesis, Harvard College, 1980.

Heckman, James D. "The Common Structure of Statistical Models of Truncation, Sample Selection, and Limited Dependent Variables and a Simple Estimator for Such Models." Annals of Economics and Social Measurement 5, no. 4 (1976): 475-492.

Lazear, Edward P. "Why is There Mandatory Retirement?" Journal of Political Economy 87, no. 6 (December 1979): 1261-1284.

"Managers who are no longer entrepreneurs." Business Week, (June 30, 1980): 74-75. 
Medoff, James L. "The Earnings Function: A Glimpse Inside the Black Box." Mimeographed. Cambridge: Harvard University, 1977.

. "Layoffs and Alternatives Under Trade Unions in U.S. Manufacturing." American Economic Review 69, no. 3 (June 1979): 380-395. and Abraham, Katharine G. "Experience, Performance, and Earnings."

Quarterly Journal of Economics 95, no. 4 (December 1980): 703-736. (a) and "Are Those Paid More Really More

Productive?: The Case of Experience." Journal of Human Resources, forthcoming. and - "Years of Service and Probability of

Promotion." Mimeographed. Cambridge: Harvard University, 1980. (b) and - "The Role of Seniority at U.S. Work

Places: A Report on Some New Evidence." Mimeographed. Cambridge:

Harvard University, 1980. (c)

Mincer, Jacob and Jovanovic, Boyan. "Labor Mobility and Wages." Working Paper no. 357, National Bureau of Economic Research, 1979.

Parsons, Donala 0. "Specific Human Capital: An Application to Quit Rates and Layoff Rates." Journal of Political Economy 80, no. 6 (December 1972): 1120-1148.

Salop, Joanne and Salop, Steven. "Self-Selection and Turnover in the Labor Market." Quarterly Journa1 of Economics 90, no. 4 (November 1976): 619-627.

Slichter, Sumner H. Union Policies and Industrial Management. Washington: Brookings, 1941.

; Healy, James S.; and Livernash, E. Robert. The Impact of

Collective Bargaining on Management. Washington: Brookings, 1960. 
U.S. Bureau of Labor Statistics. "Layoff, Recal1 and Worksharing Procedures." Major Collective Bargaining Agreements. Bulletin No. 1425-13. Washington: Government Printing Office, 1972.

Characteristics of Major Collective Bargaining

Agreements, Bulletin no. 2065. Washington: Government Printing Office, 1980.

Viscusi, W. Kip. "Self-Selection, Learning-Induced Quits, and the Optimal Wage Structure." Mimeographed. Evanston: Northwestern University, 1978. Yanker, Robert H., Jr. "Productivity Versus Seniority: What is the Determining Factor in Regard to Wages and Promotion?" Senior honors thesis, Harvard Co1lege, 1980. 
TABLE 1

EFFECT OF TENURE AND SELECTED OTHER VARIABLES ON

THE PROBABILITY OF AN EXEMPT COMPANY C EMPLOYEE'S QUIT BEING REGRETTED

$$
\begin{array}{cc}
\text { Probit Equation }^{\mathrm{a}} & \text { Maximum Likelihood } \\
(\mathrm{N}=844) & \text { Model } \\
& (\mathrm{N}=11,054)
\end{array}
$$

Less than 3 years tenure (yes $=1$ )

10 to 20 years tenure (yes $=1$ )

More than 20 years tenure (yes $=1$ )

Less than a bachelor's degree (yes $=1$ )

Master's or law degree (yes $=1$ )

Doctorate (yes $=1$ )

Quit in 1974 (yes=1)

Quit in 1975 (yes=1)

Pre-company experience dumies

Region dummies

Grade level dummies

$\chi^{2}$

d.f.
.220

(.120)

$-.057$

(.151)

$-.301$

(.335)

.140

(.170)

$-.081$

(.119)

$-.586$

(.235)

.194

(.117)

$-.159$

(.128)

2

3

9

89.1

21
.182

(.110)

$-.194$

(.149)

$-.644$

(.299)

$-.058$

(.167)

$-.057)$

(.113)

$-.528$

(.211)

.113

(.110)

$-.261$

(.120)

2

3

9

1525.2

44

a At Company C, almost every managerial or professional resignation from 1973 through 1975 was coded as "regretted," "nonregretted," or "encouraged"; inall, usable data was available for 844 white male exempt quitters who had been employed in regular full-time jobs in the continental United States prior to leaving Company $C$. The dependent variable in our probit equation was set equal to 1 if an individual's quit was "regretted" and to 0 otherwise. All of the incependent variables reflect indivicuals' status as of the date they left the company.

b The maximum likelihood model which generated the results presented in the table corrects for possible sample selection bias present in the single equation probit estimates. The sample used in estimating the model consists of white males active as of January 1 , 1973 and employed in regular full-time managerial or frofessional jobs in the continental United States as of that date plus white males who were hired or transferred into such jobs anytime between January 1, 1973 and December 31, 1975. One part of the maximum likelihood model specifies probability of quitting as a function of tenure, pre-company experience, education, region of residence, ln (annual salary) whether ever married, number of children under 18, and whether participating in the company thrift plan. All of the quit variables reflect individuals' status as of January 1, 1973 (for those in exempt postions at the company as of that date) or as of datt transferrred or hired into an exempt position (for those moving into the exempt ranks after January 1, 1973). The second part of the model specifies probability of an infividual's quit being regretted as a function of variables shown in the table. All of the regret variables reflect individuals' status as of the time they left the company.

Note: Standard errors are enclosed in parentheses below coefficient estimates. 


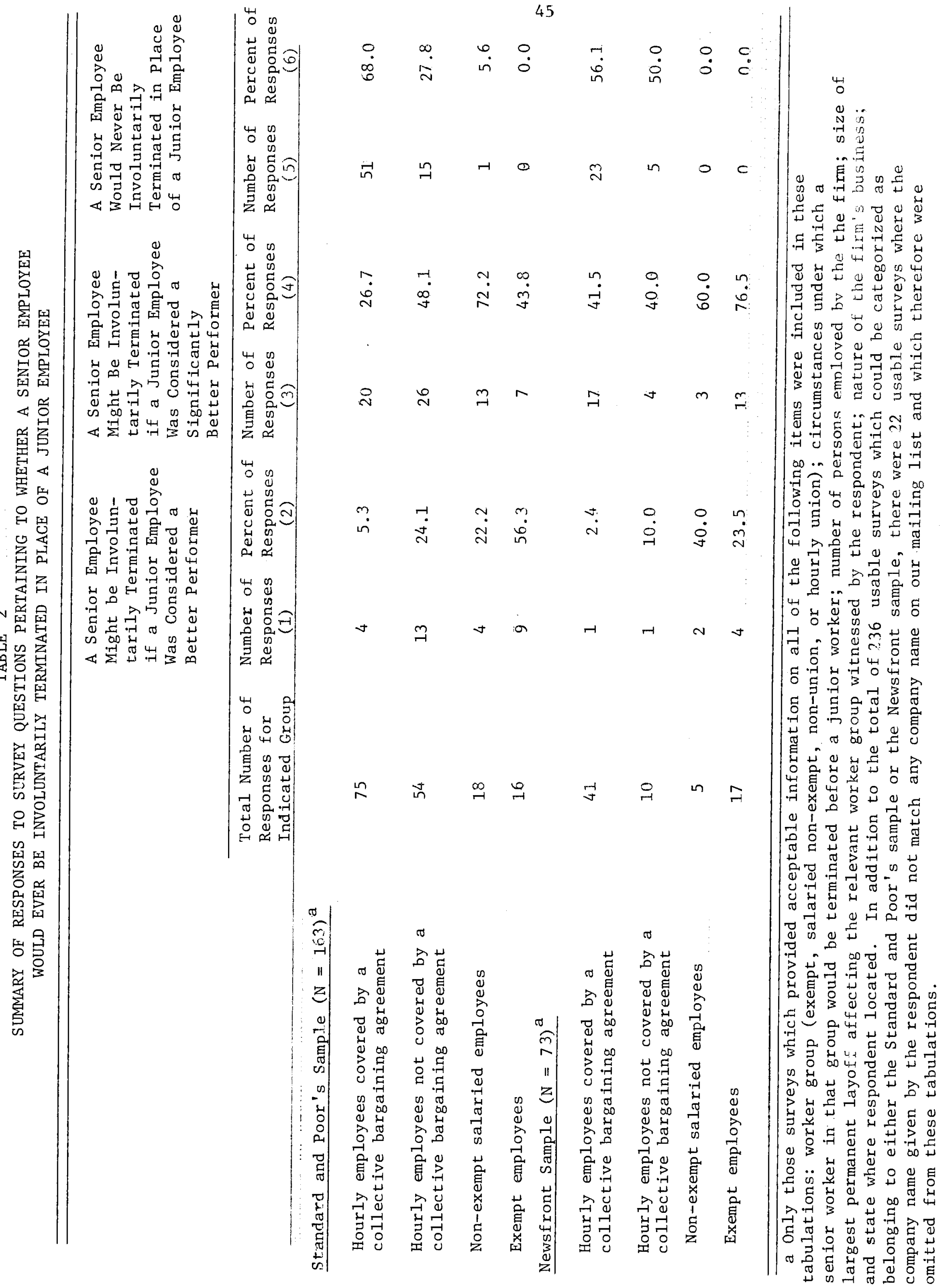


FACTORS AFFECTING THE PROBABILITY THAT A SENIOR WORKER MIGHT BE INVOLUNTARILY TERMINATED BEFORE A JUNIOR

WORKER IF THE JUNIOR WORKER WAS A BETTER PERFORMER

(ALL EMPLOYEES)

lourly employees not covered by เ collective bargaining agreelent (yes $=1$ )

lon-exempt salaried employees yes $=1$ )

ixempt employees $($ yes $=1$ )

raction laid off in largest rermanent layoff

lourly not covered by a collective argaining agreement by fraction aid off in largest permanent layoff

Ion-exempt salaried employees

.n largest permanent layoff

ixempt $x$ fraction laid off in largest iermanent layoff

n(number of persons employed

y the firm)

:n
ie
$r^{2}$

industry dummies

legion dummies ${ }^{b}$

1.f.
Dependent Variable $=1$ if

a Senior Worker May Be

Permanently Laid off if a

Junior Worker Was a Better

Performer. ${ }^{a}$

$$
(N=258)
$$

Mean

[Standard

Deviation ]

1
.549

$(.271)$

[.443]

.267

[.443]

.109

[.312]

.808

(.356)

.918

(.361)

1.083

(.486)

\section{.136}

[.343]

$$
1.354
$$

(.314)

1.373

(.316)

1.354

(.687)

$[.117$

$\begin{array}{ll}-- & 1.354 \\ & (.687)\end{array}$

.037

[. 111]

$-$

$--$

(1.944)

.007

[.035]

$-$

$-$

$-3.765$

(4.230)

.013

[.057]

$--$

$-$

6.039

(3.761)

6.89

$[2.06]^{-}$

$-.104$

$-.080$

(.056)

$-.105$

(.061)

$--$

3

3

3

3

3

3

39.4

43.2

50.6

10

11

14

a All of the models estimated for this table were probit equations. The mean of the dependent variable is .167 .

$\mathrm{b}$ The industry categories are manufacturing (omitted), transportation and communication, irade and other industries. The regions are north central (omitted), northeast, south and west. Jote: Standard errors are enclosed in parentheses below coefficient estimates. 


\section{TABLE 4}

EFFECT OF TENURE ON THE PROBABILITY OF LOSING JOB DURING A YEAR WITH. "FEW" AND DURING A YEAR WITH "MANY" TERMINATIONS AT COMPANY B'S HEADQUARTERS

Dependent Variable $=1$ if Laid off Between May $31, t$ and May $31, \mathrm{t}+1$, 0 Otherwise.

$(\mathrm{N}=1,199)$
Dependent Variable $=1$ if Laid of $f$ Between June 1, $t+1$ and November $30, t+1, a^{0}$ Otherwise. ${ }^{a}$ $(\mathrm{N}=1,257)$
Probit equation specification:

Less than 3 years tenure (yes $=1$ )

10 to 20 years tenure (yes $=1$ )

20 to 30 years tenure (yes $=1$ )

More than 30 years tenure $($ yes $=1)$

Education dummies

Pre-company experience dummies Grade level dummies

$x^{2}$

d.f.
(1)

$$
-.062
$$

$$
(.243)
$$

$-.245$

$(.227)$

$-.248$

$(.249)$

$-.268$

(.411)

(2)

3

3
2

0

9.2

3
2
8

3

8

-.154
$(.254)$
-.273
$(.239)$
-.183
$(.261)$
-.260
$(.423)$

-.045
$(.171)$
-.024
$(.137)$
.303
$(.139)$
.862
$(.170)$

(3)

$(.170)$
18.4
17

$\begin{array}{ll}.023 & .015 \\ .026 & .022 \\ .015 & .011 \\ .014 & .014 \\ .014 & .012\end{array}$
.012

$$
\begin{array}{r}
.080 \\
.087 \\
.083 \\
.145 \\
.309
\end{array}
$$

Dependent Variable $=1$ if on List of Those to be Terminated as Part of Major Staff Paring which 0ccurred Between June $1, t+1$, and November 30 , $t+1,0$ Otherwise.

$(\mathrm{N}=1,257)$

Estimated probability of a sample member with the indicated amount of tenure and otherwise average Less than 3 years tenure 3 to 10 years tenure 20 to 30 years tenure More than 30 years tenure (4). (5) (6)

$\begin{array}{ccc}(4) & (5) & (6) \\ & & \\ -.081 & -.001 & -.084 \\ (.179) & (.156) & (.165) \\ .020 & .086 & .150 \\ (.141) & (.123) & (.127) \\ .410 & .320 & .412 \\ (.146) & (.128) & (.134) \\ 1.025 & .903 & 1.039 \\ (.178) & (.158) & (.165)\end{array}$

$(.178)$

3

3

2

12

2

2

14

$\begin{array}{ccc}85.5 & 67.3 & 101.1 \\ 21 & 9 & 23\end{array}$


THE RELATIONSHIP OF TENURE TO LN (HOURLY WAGE)

IN THE PANEL STUDY OF INCOME DYNAMICS (PSID) DATA

\begin{tabular}{|c|c|c|c|c|}
\hline & \multicolumn{2}{|c|}{1971 Regressions } & \multicolumn{2}{|c|}{1974 Regressions } \\
\hline & $\begin{array}{l}\text { Blue } \\
\text { Collar } \\
(N=479)\end{array}$ & $\begin{array}{l}\text { Managerial } \& \\
\text { Professiona }]^{a} \\
\quad(N=241)\end{array}$ & $\begin{array}{l}\text { Blue } \\
\text { Collar } \\
(N=541)\end{array}$ & $\begin{array}{l}\text { Managerial \& } \\
\text { Professional } \\
\qquad(N=278)\end{array}$ \\
\hline $\begin{array}{l}\text { Mean (standard deviation) } \\
\text { of the dependent variable }\end{array}$ & $\begin{array}{l}5.941 \\
(.369)\end{array}$ & $\begin{array}{l}6.359 \\
(.440)\end{array}$ & $\begin{array}{l}6.108 \\
(.399)\end{array}$ & $\begin{array}{l}6.465 \\
(.492)\end{array}$ \\
\hline $\begin{array}{l}\text { Proportion of sample with: } \\
\text { Less than } 3 \text { years tenure } \\
3 \text { to } 10 \text { years tenure } \\
10 \text { to } 20 \text { years tenure } \\
\text { More than } 20 \text { years tenure }\end{array}$ & $\begin{array}{l}.397 \\
.230 \\
.217 \\
.157\end{array}$ & $\begin{array}{l}.415 \\
.282 \\
.178 \\
.124\end{array}$ & $\begin{array}{l}.370 \\
.309 \\
.174 \\
.148\end{array}$ & $\begin{array}{l}.432 \\
.291 \\
.147 \\
.129\end{array}$ \\
\hline Regression specification & & & & \\
\hline $\begin{array}{l}\text { Less than } 3 \text { years tenure } \\
\quad \text { (yes }=1 \text { ) } \\
\text { to to } 20 \text { years tenure } \\
\quad \text { (yes }=1 \text { ) } \\
\text { More than } 20 \text { years tenure } \\
\quad \text { (yes }=1 \text { ) }\end{array}$ & $\begin{array}{l}-.132 \\
(.039) \\
.047 \\
(.044) \\
.159 \\
(.049)\end{array}$ & $\begin{array}{l}-.165 \\
(.066) \\
.072 \\
(.084) \\
.109 \\
(.092)\end{array}$ & $\begin{array}{l}-.198 \\
(.038) \\
.011 \\
(.047) \\
.099 \\
(.050)\end{array}$ & $\begin{array}{l}.149 \\
(.064) \\
.234 \\
(.086) \\
.419 \\
(.089)\end{array}$ \\
\hline Industry dummies & 10 & 10 & 10 & 10 \\
\hline $\begin{array}{l}\text { Occupation dummies } \\
\mathrm{R}^{2}\end{array}$ & .274 & .174 & .213 & .266 \\
\hline
\end{tabular}

a All of the models estimated for this table were ordinary least square regressions. Each of the samples consisted of male residents of the continental U.S. who were employed full-time in the private sector as of the relevant interview date in industries other than agriculture and construction, reported a wage of $\$ 1.60$ per hour or greater, and were in appropriate occupations. Members of households in the PSID low income samples were excluded from the analysis. The 1971 (1974) regressions have ln (Average Hourly Wage) during 1970 (1973) as the dependent variable and independent variables derived from information given at the time of the 1971 (1974) interview.

Note: Standard errors are enclosed in parentheses below coefficient estimates. 
APPENDIX B

SUMMARY OF STUDIES PERTAINING TO THE RELATIONSHIP OF TENURE, EXPERIENCE AND AGE TO PRODUCTIVITY

Subject Group and Study
Methociology and Conclusions
Exempt employees at two large manufacturing firms (Medoff and Abraham [forthcoming a]).

Exempt employees at a large manufacturing firm (Medoff and Abraham [forthcoming b]).

Production and warehouse employees at a nonunion manufacturing; plant (Halasz [I980]).

Blue collar employees at a unionized manufacturing plant (Yanker [1980]).

Recently-hired first line supervisors at a manufacturing plant (Brown [1979]).
Data on salary, performance rating assigned by supervisor, job grade leve1 and individua1 characteristics for severa1 thousand white male employees at each of two large companies were taken frotn those companies' computerized personnel files. At both companies approximately 40 percent of the higher earnings associated with seniority took the form of higher earnings within grade level. While additional company service beyond the mean amount increased the probability of being towards the top of the within-grade-level salary distribution, it decreased the probability of being towards the top of the within-grade-level performance distribution.

Cross-sectional results virtually identical to those in Medoff and Abraham (forthcoming a) were obtained with data for approximately 8,000 exempt employees of a third large company. In addition, analysis of longitudinal data on pay and performance revealed that, for those staying in the same job grade level over time, relative within-gradelevel salary rose but relative within-grade-level rated performance fell.

Salary, performance rating, job grade level and information on individual characteristics were taken from approximately 300 non-exempt employees' personnel records. For these employees, approximately 50 percent of the return to seniority took the form of higher earnings within grade level. Additional company service beyond the mean amount increased the probability of being towards the top of the withingrade-level salary distribution but decreased the probability of being towards the top of the within-grade-level performance distribution.

Data on hourly rate of pay, productivity, job grade level and individual characteristics for approximately 400 workers were taken from their personnel records. The productivity measure was equal to the time the worker took to do his/her job divided by the standard time for performing the job. Approximately 80 percent of the earnings return to seniority occurred within job grade level; none of this within-grade-level return could be explained on the basis of more senior workers having higher productivity.

Performance ratings for approximately 200 persons hired over a six year period were used in the analysis. Other factors the same, years in supervisory position had a positive affect on rated performance. However, the mean amount of company service among those in the sample was only three years. 


\section{SUMMARY OF STUDIES PERTAINING TO THE RELATIONSHIP OF TENURE, EXPERIENCE AND AGE TO PRODUCTIVITY \\ (cont inued)}

Subject Group

Methodology and Conclusions

and Study

Scientists

(Cole [1978]).

Airline

managers

(Medoff [1977]).

Sixth grade

tuachers

(Summers and

Wolfe [1977]).

Scientists and engineers

(Hall and

Mansfield

[1975]) .

Inner-city

third

grade

teachers

(Murnane

[1975]).

Enginewis in technology-based commerical industries (Dalton and Thompson [1971]).
Cross-sectional data for a random sample of U.S. scientists in $\mathrm{six}$ disciplires showed a peak among those aged 40 to 44 both in mean number of papers published and in the importance of published rorks as measured by number of citations. However, a11 differences in mean output between adjacent age groups were very small. Longitudinal data for the cohort of U.S. mathemeticians who got their Ph.D.' s between 1947 and 1950 showed no relationship between time since receiving $\mathrm{Ph} . \mathrm{D}$. and either number of publiciations or number of citations to those publications.

Cross-sectional results very similar to those in Medoff and Abraham (forthcoming a) were obtained using data for approximately 800 managers. employed by an airline.

The change between third grade and sixth grade in individual students' composite achievement score on the Iowa Test of Basic Skills was used as a measure of educational output. Sixth grade teachers' experience was measured in years up to 11 years. A total of 627 usuable observations were obtained. Controlling for other factors, students whose thixd grade scores were above the norm benefitted from additional sixth grade teacher experience, but among those with third grade scores below the norm, additional teacher experience was associated with smaller changes in test score.

Performance data was collected for 290 researchers in 22 research and development organizations using questionnaires which asked people to rate their own performance relative to others in similar positions by placing themselves on a 7 point scale ranging from "in top $5 \%$ " to "in the lower 25\%". The same questionnaire was readministered to 90 of the researchers two years later. Cross-sectional analyses of the two sets of responses found self-rated performance to be uncorrelated with seniority.

Progress made during third grade in math and in reading by each of approximately $900 \mathrm{black}$ students was measured using changes in the students' standard scores on Metropolitan Achievement Tests. Controlling for other factors, the biggest improvement in students' test scores was observed for teachers with three to four years of experience. Teachers with five or more years of experience were found to be no more effective or less effective than teachers with three or four years of experience.

Three measures of performance were collected for approximately 2,500 design and development engineers at six companies: performance ratings done by management; (2) management evaluations of the complexity of engineers' assignments; and (3) engineers' own assessments of what happens to the productivity of those doing technical work as they age. Rated performance was highest for those 
SUMMARY OF STUDIES PERTAINING TO THE RELATIONSHIP OF TENURE, EXPERIENCE AND AGE TO PRODUCTIVITY

(continued)

Subject Group and Study
Methodology and Conclusions
Third grade teachers

(Hanushek [1970].

Male production managers ( $T$ enopyr [1969]).

Research scientists (Eiduson [1966]).

Research chemists (Stewart and Sparks [1966]). aged 31 to 35 and fell off sharply thereafter. Those 26 to 30 performed the most complex tasks, with older engineers doing much less complex work. The engineers themselves said peak productivity for those doing technical work occurred at age 38 . However, salaries were substantially higher for those in each successive age bracket through the 41 to 45 year old group and were level beyond age 45 .

Cross-sectional data from a survey covering 1,061 third-grade students in a large California school system was used. Individual students' third grade Stanford Achievement test scores were used as a measure of educational output. Controlling for students' first grade test scores and other relevant factors, neither second grade teachers' experience nor third grade teachers' experience was found to have any significant effect on third grade test score.

Data was collected on 113 male production managers in one division of a rocket engine development and manufacturing concern. The study focused on how well various tests of leadership potential predict managerial success, but included a correlation analysis of seniority versus performance. Two measures of performance were used: (1) immediate supervisors were asked to check descriptive statements about each manager and integral weights from 0 to 4 were applied in scoring the checklists; and (2) the company's labor relations staff rated the manager's handling of employee relations matters on a 7-interva1 scale. For the 86 subjects for whom both performance measures were available, seniority was not found to be significantly correlated with either rating.

Longitudinal data on average number of papers published per year during each of two successive five year periods was collected for 40 research scientists ranging in age from their $30^{\prime}$ 's to their $60^{\prime} \mathrm{s}$. Subjects' curriculum vitae were the source of the publication information. Productivity was steady for those aged 30 to 39 at the end of the first five year period, grew slightly for those aged 40 to 49, and fell off for those aged 50 or greater.

Number of patent memoranda, number of patent applications and number of patents issued were used as measures of productivity. Altogether 962 man-years worth of data for 89 men in one division of a large industrial scientific research organization were collected. Each of these 962 man years was treated as a separate observation in a cross sectional analysis. All three patent variables were positively correlated with length of service; however, the positive association between patent activity and lengtin of service was much weaker beyond 10 years of service than prior to that cutoff. 
SUMMARY OF STUDIES PERTAINING TO THE RELATIONSHIP OF TENURE, EXPERIENCE AND AGE TO PRODUCTIVITY

(continued)

Subject Group and Study
Methodology and Conclusions
Emntoyees of one multidepartment $f$ irr. (Svetik, Prien, and Barnet [1966]).

Federal mail sorters (Bureau of Labor Statistics [1964]).

Scientists and cnrincors in research laboratories (Pelz [1964]).
Supervisors were asked to complete a performance evaluation of each of their subordinates, rating them on "overall effectiveness," which was not explicit].y defined. A significant negative correlation was found between these ratings and individual employees' length of service. The supervisors' ratings were also negatively correlated with salary.

Production records covering an eight week period for approximately 6,000 workers in twelve cities were analyzed. An index of performance was computed for each worker by dividing his/her production score by the average production score of all workers aged 35 to 44 doing similar work in the sane city. Those with less than six months service had the lowest average performance index; beyond six months, length of service seemed to be unimportant.

Five measures of current performance were collected for a cross-section of 1,311 scientists and engineers working in 11 research laboratories: (1) contribution to scientific knowlege, as judged by colleagues; (2) overall usefulness to laboratory, again as judged by colleagues; (3) published papers; (4) patent applications; and (5) unpublished papers. A11 the performance measures were for the five year period prior to the date of the study. For those in research laboratories, measured performance typically was highest among those aged $35-44$ as of the time of the study; for those in development laboratories, the peak occurred among those 45 to 49. Performance among those immediately beyond the peak age group was sharply lower. A second peak in performance was evident 10 to 15 years beyond the first performance peak.

Data on physical volume of production per hour worked over an observation period of 4 to 12 weeks was collected for approximately 6,000 workers in 5 federal agencies and 21 private companies. An index of performance was computed for each worker by taking the ratio of his/her output to the average output of those aged 35 to 44 employed at the same firm and doing comparable work. Among workers with 9 months or more experience on the job, there was practically no difference in the mean value of the performance index across age groups, either within occupational groups or when an average was taken across the occupational groups. A large proportion of those included in the sample were under incentive payment schemes. However, the results looked very similar for those under incentive and those under time payment plans, 
SUMMARY OF STUDIES PERTAINING TO THE RELATIONSHIP OF TENURE, EXPERIENCE AND AGE TO PRODUCTIVITY

(continued)

Subject Group

Methodology and Conclusions and Study

Technical employees in a large research and engineering firm (Oberg [1960]).

Retail sales personnel (Canadian Department of Labor [1959]).

Production workers in the wood household furniture industry and the footwear industry (Bureau of Labor Statistics [1957]).

Production workers in the footwear industry and the clothing industry (Bureau of Labor Statistics [1956]).
Performance of approximately 900 technical employees in one firm was estimated using cross-sectional data on individuals' positions in the annual order-of-merit rankings of technical employees. These rankings were done on a department by department basis for salary administration purposes. The criterion used in ranking was the workers' "present value to the compnay". This criterion was not defined more precisely. Among those doing research and development work, performance was highest for those 30 to 35 and fell off gradually thereafter. Among those doing engineering work, performance fell off for those aged 32 through 50 , then showed a second peak for those in their 50's.

The dollar volume of sales for clerks in two large department stores were used to form performance ratings of 1 through 4, depending on each individuals' quartile postion in the distribution of dollar sales for his/her department. At one store, mean rated. performance was lower for those with less than 3 years service than for those in the longer service groups, and weakly but positively related to service thereafter. At the second store, mean rated performance was lower for those with less than 6 years service than for those with more service and again weakly but positively related to service thereafter.

For approximately 5,100 workers in 15 footwear establishments and 11 furniture establishments, output per worker-hour was measured using average straight time hourly piecework earnings. The production index used for comparison purposes was each individual's average hourly earnings divided by the mean of average hourly earnings for those of the same sex in the 35 to 44 age group doing the same job in the same plant. In both industries and for both sexes, the mean value of the production index was highest for those aged 25 to 34 and fell off beyond that age group.

Piecework earnings data for 933 workers in the footwear industry and 1,284 workers in the clothing industry was studied. The data were used to create a production index like that used in Bureau of Labor Statistics (1957). The mean value of this production index was stable for all age groups through age 54 and approximately 10 percent lower for those aged 55 to 64 . 
SUMMARY OF STUDIES PERTAINING TO THE RELATIONSHIP OF TENURE, EXPERIENCE AND AGE TO PRODUCTIVITY

(continued)

Subject Group

Methodology and Conclusions and Study

Outstanding people in a variety of professiona 1 occupations (Lehman [1953]).

Shopcraft railroad employees (Mater [1941])

Employees of large New England manufacturing companies (Palmer and Browne11 [1939]).
The goal of this study was to identify the age by which numerous individuals in various fields had done their best work or achieved their highest average rate of productivity. In the majority of occupations, it was found that the individulas' best work had been done by age 40. However, it should be emphasized that the study focused on selected outstanding individuals rather than on a representative sampling of members of any occupation.

Relative speed of work for a cross-section of 701 employees of one railroad was used as a measure of worker efficiency. Holding age constant, efficiency appeared to peak at about 10 years of service and fall off thereafter.

Records on productivity of workers at six companies were obtained and broken down into a comparison of productivity by age groups for 172 textile weavers, 127 textile spinners and 147 workers in nonferrous metal manufacturing. The records did not show any tendency for productivity to vary with age. 


\section{Sources cited:}

Brown, Charles. "Estimating the Determinants of Employee Performance." Working Paper no. 353. National Bureau of Economic Research, 1979.

Canadian Department of Labor Economics and Research Branch. Age and Performance in Retail Trade. Ottawa: The Queen's Printer and Controller of Stationery, 1959.

Cole, Stephen. Age and Scientific Performance. New York: Center for the Social Sciences, Columbia University, 1978.

Dalton, Gene W., and Thompson, Paul H. "Accelerating Obsolescence of Older Engineers." Harvard Business Review 49, no. 5 (September-October 1971): 57-67.

Eiduson, Bernice T. "Productivity Rate in Research Scientists." American Scientist 54, no. 1 (1966): 57-63.

Halasz, Peter Jonathan. "What Lies Behind the Slope of the Age-Eariings Profile." Senior honors thesis, Harvard College, 1980.

Hal1, Douglas T. and Mansfield, Roger. "Relationships of Age and Seniority with Career Variables of Engineers and Scientists," Journal of Applied Psychology 60 , no. 2 (1975): 201-210.

Hanushek, Eric. "The Production of Education, Teacher Quality, and Efficiency." In Do Teachers Make a Difference? Office of Education, Department of Health, Education and Welfare. Washington: Government Printing Office, 1970.

Lehman, Harvey C., Age and Achievement. Princeton: Princeton University Press, 1953.

Mater, Tan H., "A Statistical Study of the Effect of Seniority Upon Employee Efficiency," Journal of Business of the University of Chicago 14, no. 2 (April 1941): 169-204.

Medoff, James L. "The Earnings Function: A Glimpse Inside the Black Box." Mimeographed. Cambridge: Harvard University, 1977.

and Abraham, Katharine G. "Experience, Performance, and Earnings." Quarterly Journal of Economics 95, no. 4 (December 1980): 703-736. and - "Are Those Paid More Really More Productive?" The Case of Experience." Journal of Human Resources, forthcoming. Murnane, Richard J. The Impact of School Resources on the Learning of Inner City Children. Cambridge, Massachusetts: Ballinger, 1975.

Cberg, Winston, "Age and Achievement--and the Technical Man." Personnel Psychology 13, no. 3 (Autumn 1960): 245-259. 
Palmer, Dwight L., and Brownell, John A. "Influence of Age on Employment Opportunities," Monthly Labor Review (Apri1 1939): 765-780.

Pelz, Donald C. "The 'Creative Years' and the Research Environments." LEEE Transactions on Engineering Management Vo1. EM-11, no. 1 (March 1964): $\frac{\text { LEE }}{23-29 .}$

Stewart, Naomi, and Sparks, William J. "Patent Productivity of Research Chemists as Related to Age and Experience." Personnel and Guidance Journal 45 (September 1966): 28-36.

Summers, Anita A., and Wolfe, Barbara L. "Do Schools Make a Difference?" The American Economic Review 67, no. 4 (September 1977): 639-652.

Svet1ik, Byron, et. a1. "Relationships Between Job Difficulty, Employee's Attitude Toward His Job, and Supervisory Ratings of the Employee Effectiveness." Journal of Applied Psychology 48, no. 5 (1964): 320-324.

Tenopyr, Mary L. "The Comparative Validity of Selected Leadership Scales Relative to Success in Production Management." Personne1 Psychology 22, no. 1 (1969): 77-85.

U.S. Bureau of Labor Statistics. Comparative Job Performance bv Age: Large Plants in the Men's Footwear and Household Furniture Industries. Bulletin No. 1223. Washington: Government Printing Office, November 1957.

mance by Age: Office Workers. Bulletin No. 1273. Washington: Government Printing Office, February 1960.

- Job Performance and Age:

A Study in Measurement. Bulletin No. 1203. Washington: Government Printing Office, September 1956.

."The Job Performance of of Federal Mail Sorters by Age." Month1y Labor Review, March 1964, pp. 296-300.

Yanker, Robert H. Jr. "Productivity Versus Seniority: What is the Determining Factor in Regard to Wages and Promotion?' Senior honors thesis, Harvard College, 1980 . 
Please return to:

CONFTEETAL

No information you submit will be fdentified whth you or your corpany without your tritten permission.

Professor James L. Medoff Departient of Ecoromics 115 Littauer Center Harvard University Cambridge, MA 02138

HUMAN RESOURCES REGFARCH PEOJECT

E:PLOYEE SEPARATIONS SURVEY

You should arswer this survay orly if: (1) you are enoloyed by a provatesector, for profit fira whose principai activity is refther agriculture nor construction; (2) you make derisicrs concerning the managerent of human resources affecting employees other than those whon you supervise directiy.

If you do not fit the above description, please just conplete the mailing address below and return this form in the enclosed preadoressed envelope.

Compary name:

Your rame and title:

Your adiress:

Your telephone number:

As part of our ongoing huan resources research program, we are curcent ly conducting a comprehensive siudy of involuntary separations at U.S. companies, Our gonl is to generate a substantial amount of explcical evidence on companies' dacisions regarding employdent cutbacks. We believe such inforation should be of great value and interest to many managers.

This survey is priarily concerned with the factors that influence mandgement dectsions pertaining to enploment cutbacks. Other components of our research effort include computer analysis of data from a number of major U.S. corporations and in-depth interviews with officials at thcse same firms.

Completing this questionnaire should take no more than five minutes of your time. Your cooperation will be invajuable to our research effort:

If you would like us to send you a personal copy of our sumary report, please be sure you have given us your mailing address above and check the appropriate box.

I would like a personal copy of the summary report. $\square$ Yes. $\square$ No.

1. Approximately how many people are employed by your company?

2. What is the principal product or service supplied by your company?

3. How would you classify the largest group of employees who are affected by your decisions concerning the management of human resources?

Hourly. $\square$ Non-exempt salary. $\square$ Exempt.

4. Are the majority of the members of the group you checked in question 3 covered by either a written company policy pertaining to conditions of enploysent or by a collective bargaining agreement?

Yes, by a written company policy.

Yes, by a collective bargaining agreement.

No (PLEHSE SKIP TO QUESTION 9). 
5. Does this written polfcy or collective bargainirg agroement deal with promotions?

$\square$ ies. $\square$ iro (PEEASÉ SKIP To juestion 7).

6. Under the terms of the policy or agreerent, is seniority the most important factor in awarding promotions?

$\square$ Yes. $\square$ No.

7. Does this written policy or collective bargaining agreement deal with permanent lay of $\mathrm{f} s$ ?

$\square$ Yes. $\square$ No (PLEASE SKIP TO QUESTION 9).

8. Under the terns of the policy or agreenent, is seniority the most important factor in determining who is permanenty laid off during any rediction in the workforce?

$\square$ Yes. $\quad \square$ No.

9. In actual practice, wouli one of tine junior employees in the group you checked in question 3 ever be pronoted instead of a more senior errployee who wanted the job?

Yes, if the junior employee was considered a better performer than the senior employee.

$\square$ Yes, if the junior employee was considered a significantly better performer than the senior employee.

No, never.

10. In the event of a reduction in the workforce, would ore of the senior empioyees in the grow you checked in question 3 ever be involutarily teranated, bhat is, laid off permanently against his or her will, in place of a junior employee?

Yes, if the junior employee was considered a better performer than the senior employee.

Yes, if the junior employee was considered a slgnificantly better performer than the senior employee.

$\square$ No, never.

11. During the years in which you have been involved in decision making in the human resources area, have permanent layoffs ever been used to reduce the size of the group you checked in question 3 ?

$\square$ No, never (PLEASE STOP HERE).

$\square$ Yes, permanent layoffs have been used once or twice.

Yes, permanent layoffs have been used more than twice.

12. What percent of the group you checked in question 3 was permanently laid off in your most recent reduction of the workforce?

percent.

13. What percent of the group you checked in question 3 was permanently lafd off in the next most recent reduction of your workEorce?

percent.

Does not apply. We have used permanent layofís only once.

Thank you for your help. Please return this questionnaire in the enclosed envelope. 